\title{
PSA Level Less than 0.7
}

National Cancer Institute

\section{Source}

National Cancer Institute. PSA Level Less than 0.7. NCI Thesaurus. Code C141204.

A blood concentration of prostate specific antigen less than $0.7 \mathrm{ng} / \mathrm{mL}$. 